Arthur, R. (2005) Punishing Parents for the Crimes of their Children, of Criminal Justice 44, 3, 233.

\title{
Punishing Parents for the Crimes of their Children
}

\section{Raymond Arthur}

\begin{abstract}
In recent years there has been a profusion of laws that punish parents for their children's offences. These parental responsibility laws are based on the assumption that parents of children who offend have not accepted their responsibility and that they can be made to do so by the imposition of court orders and financial penalties. In this paper I will examine the efficacy of punishing parents for the crimes of their children. I will consider whether parental responsibility laws are an effective means of tackling youth crime; or should policies that strengthen the family and improve parenting skills be pursued as strategies for preventing juvenile offending behaviour.
\end{abstract}

Keywords: Anti-Social Behaviour Act 2003, juvenile offending, penalising parents, family support.

Dr Raymond Arthur

Lecturer in Law,

Centre for Law,

The Open University,

Walton Hall,

Milton Keynes MK7 6AA.

Email: R.Arthur@open.ac.uk

Tel: 01908655893 


\title{
Punishing Parents for the Crimes of their Children
}

\begin{abstract}
In recent years there has been a profusion of laws that punish parents for their children's offences. These parental responsibility laws are based on the assumption that parents of children who offend have not accepted their responsibility and that they can be made to do so by the imposition of court orders and financial penalties. In this paper I will examine the efficacy of punishing parents for the crimes of their children. I will consider whether parental responsibility laws are an effective means of tackling youth crime; or should policies that strengthen the family and improve parenting skills be pursued as strategies for preventing juvenile offending behaviour.
\end{abstract}

\section{Introduction}

The Anti-Social Behaviour Act 2003, which received Royal Assent in November 2003, is the latest instrument in the government's fight on youth crime. In the White Paper which preceded the Anti-Social Behaviour Bill, Respect and Responsibility (Home Office 2003), the government outlined what it believed to be the causes of juvenile anti-social behaviour and the measures it intended to take to combat the problem. Families and family life featured heavily as both a cause and a solution to youth offending. The White Paper proposed that intervention and support should be provided to families where their children's dysfunctional and delinquent behaviour is ruining other people's lives and "where families and parents are failing to meet their responsibilities to their communities, we will work with them until they do. Where people need our support, we must provide it" (Home Office 2003: 5) Two weeks after the White Paper was published, and with no consultation, the Anti-Social Behaviour Bill was introduced and subsequently became law on the $21^{\text {st }}$ November 2003. The Anti-Social Behaviour Act adopted a more punitive attitude towards the families of juvenile offenders. Instead of providing families with support, the Act 
serves to underline the government's intention to punish and penalise the parents of persistent young offenders.

In this article I will examine the provisions of the Anti-Social Behaviour Act 2003, and other related legislation, that penalise parents for their children's behaviour. I will consider evidence from over half a century of criminological research that establishes that the focus of parental involvement in delinquency cases should be on the treatment and rehabilitation of the child and on the parent's role in facilitating their child's development rather than punishing parents. I will contend that legislation that punishes parents for their children's offending not only disregards this overwhelming criminological evidence but also flouts Britain's obligations under domestic and international law. I will argue that these laws do not represent a serious attempt to tackle the root causes of youth offending but instead merely reflect successive governments' proclivity for talking tough on youth crime.

\section{Parental Responsibility Laws in England and Wales}

The parental responsibility provisions of the Anti-Social Behaviour Act 2003 are not a new development; parental responsibility laws have been part of the response to youth offending since the nineteenth century. In this section I will examine the history of parental responsibility laws in England and Wales.

\section{- Enforcing Parental Responsibility for Juvenile Offending: pre-1990s}

Enforcing parental responsibility for juvenile offending has been a characteristic feature of the history of youth crime control since the nineteenth century. The Youthful Offenders Act 1854 permitted the setting up of reformatory schools by voluntary societies to contain and morally re-educate 'deviant' children. 
Under the Reformatory Schools Act 1884 children between 5 and 16 years of age could be sent to reformatory school for up to two years and their parents could be ordered to pay for their upkeep. The payment of maintenance was intended to enforce parental responsibility. The establishment of industrial schools also ensured that parents were required to contribute to the maintenance of their children. Children found begging or who had no visible means of subsistence were deemed to be beyond parental control and could be sent to an industrial school indefinitely, under the Industrial Schools Act 1857. The burden of maintenance created an incentive for parents to conform to the dominant middle class child-rearing practices (Muncie 1999a). Parental shortcomings were thus viewed as a fundamental cause of juvenile offending behaviour and the state aimed to compel responsible behaviour on the part of parents. The Children and Young Persons Act 1933 was the first Act to empower the courts to require parents to pay the fines of a juvenile offender. The Criminal Justice Act 1982 ordered parents to pay a juvenile offender's fines or compensation. Accordingly, by the time of the Criminal Justice Act 1991 specific measures were available which allowed for the imposition of financial penalties upon parents when crimes were committed by their children.

\section{- $\quad$ The Criminal Justice Act 1991}

In a White Paper published in February 1990 the government expressed its intention to take further measures to enforce parents' responsibility for the criminal acts of their children aged between 10 and 16 years (Home Office 1990). Originally it wanted to make it a criminal offence for parents to "fail to prevent their children from committing offences." However this proposal was heavily criticised by, among others, the Magistrates' Association and was subsequently dropped. The main criticisms were 
that most delinquents ${ }^{1}$ came from families that were inadequate in some way and they tended to live a chaotic lifestyle. Most young offenders lives are characterised by economic and social disadvantage, family breakdown and a lack of a positive role model such as an appropriate father figure. It was argued that resources could better be diverted to helping such families through education and social work support. It was further argued that the proposal was likely to be counter-productive in that it might lead to the complete disintegration of already fragile family units (West 1982). Despite these criticisms, the first law in England and Wales which held parents directly responsible, as opposed to financially liable, was enshrined in the Criminal Justice Act 1991. Section 58 of the 1991 Act requires a parent to accompany to court any of their children, aged between 10 and 16 years and accused of a criminal offence, and to pay any fine and/or costs. The most significant aspect of the 1991 Act was the introduction of the parental 'bind over'. The parent could be 'bound over' by the court to exercise control over an offending child. Failure to meet the terms of the bind over could result in a fine of $£ 1000 .^{2}$ This is the first time that parents have been fined for their failure to control their children's behaviour. In relation to a young person between 10 and 16 years of age, this power must be exercised where the court is satisfied that it would be desirable in the interests of preventing the commission of further offences by the offender. ${ }^{3}$ If the court is not satisfied that it would be appropriate to impose a bind over on the parents of an offender under 16 years, it must state openly why it is of this opinion. ${ }^{4}$ The rationale for this approach to juvenile offending and parental responsibility was set out clearly by the then Minister of State at the Home Office, John Patten, who described the families of young offenders as families who: 
"could cope but simply chose not to...these are families which have failed not through misfortune or misjudgement, but through wilful neglect by parents of their responsibilities."

\section{- $\quad$ The Crime and Disorder Act 1998}

The Crime and Disorder Act 1998 built upon this principle of parental responsibility by introducing the 'parenting order' enabling the court to require the parent of every convicted juvenile offender ${ }^{6}$ to attend parenting programmes and if necessary to control the future behaviour of the juvenile in a specified manner. The parenting programmes deal with issues such as experiences of parenting, communication and negotiation skills, parenting style and the importance of consistency, praise and rewards and can include a residential element. ${ }^{7}$ In effect, the parenting order requires a parent to attend counselling or guidance sessions once a week for a maximum of 12 weeks. Parents may also be required to apply control over their child, for example they may be ordered to ensure their child attends school or avoids associating with particular individuals who are adversely affecting their behaviour. The court may impose a parenting order in the following circumstances: ${ }^{8}$ where a child safety order has been made in respect of a child; ${ }^{9}$ where an anti-social behaviour order, or sex offender order, is made on a child or young person; ${ }^{10}$ where a person is convicted of an offence under section 443 (failure to comply with a school attendance order) or section 444 (failure to secure regular attendance at school of registered pupil) of the Education Act 1996; or where a referral order has been made. ${ }^{11}$ The relevant condition that has to be satisfied to justify making a parenting order is that the order is desirable in the interests of preventing any repetition of the kind of behaviour that led to the order being made and the prevention of further offending by the child or young person. Should a parent fail to comply with the requirements of the order they may be liable to a fine of up to $£ 1000$. 
In 1997 the Home Office consultation paper Tackling Youth Crime first detailed the underlying principle of the parenting order, which was to make "parents who wilfully neglected their responsibilities answerable to the court" (Home Office 1997a: para. 32). This consultation paper was followed by the White Paper No More Excuses: A New Approach to Tackling Youth Crime in England and Wales (Home Office 1997b) which stated that the government intended to make parents more responsible for their children's behaviour by making available sanctions for parents who evade their responsibilities. When introducing the Crime and Disorder Act 1998 the then Home Secretary, Jack Straw, stated that the parenting order would help to confront parents with their responsibilities and respond to the crime breeding 'excuse culture' which allows young people to continue "wasting their own and wrecking other people's lives" (Straw 1998: 2). He envisaged that parenting orders would provide a mechanism for coercing parents who are 'unwilling' to address their child's behaviour.

\section{- The Anti-Social Behaviour Act 2003}

The Anti-Social Behaviour Act 2003 perpetuates the statutory assumption that parents of children who offend have not accepted their responsibility and that they can be made to do so by the imposition of court orders and financial penalties. Section 87(3) of the 2003 Act allows for the issuing of Fixed Penalty Notices to parents of offenders between the ages of 10 and 16. The Anti-Social Behaviour Act also increases the circumstances in which a parenting order can be made. Section 26 empowers Youth Offending Teams (YOTs) to apply to the courts for parenting orders where the YOT suspects that the parent is not taking active steps to prevent the child's anti-social or criminal type behaviour, and it is clear that this behaviour will continue. 
Local education authorities will also be able to seek a parenting order where a child has been excluded from school for serious misbehaviour. ${ }^{12}$ The Minister of State at the Home Office, Baroness Scotland of Asthal, described the Anti-Social Behaviour Act 2003 as a necessary tool in underlining the responsibility of parents to teach their children the difference between right and wrong. She believed that where families are reluctant or incapable to accept this role, the 2003 Act empowers the court to order the parents to participate in an appropriate programme of support. ${ }^{13}$

The punitive ethos of the Reformatory Schools Act 1884, the Industrial Schools Act 1857, the Children and Young Persons Act 1933, the Criminal Justice Act 1982, the Criminal Justice Act 1991, the Crime and Disorder Act 1998 and the Anti-Social Behaviour Act 2003 produces a powerful impact which tends to undermine rather than reinforce the ability of parents to offer their children help and guidance. The accusation is blunt - All parents are to blame for the delinquent acts of their children; and imposing financial penalties upon such parents is considered an appropriate way to prevent youth offending. The parental responsibility laws ignore the evidence that suggests a far more complex inter-relationship between parents, their children and juvenile offending behaviour. A better understanding of offending by young people is required in order to develop effective steps to reducing juvenile offending. Therefore in the next section I will consider the association between parenting and youth crime and assess whether penalising parents for the delinquent acts of their children is an efficacious way of preventing youth offending and antisocial behaviour. 


\section{Parenting and Youth Crime}

Criminological research conducted over fifty years has clearly documented many correlates of juvenile offending behaviour (Farrington 1996; Utting 1996; West 1982). Significantly throughout the literature, the family has been regarded as a major influence in the presence or absence of youth offending. This research has shown that the major contributing factors within the family to the development of criminal propensities are to be found in the child rearing and parenting processes (Farrington 1996; Kolvin et al 1990). These explanations of youth crime suggest that the relationship between parent and child is the causal mechanism that determines whether tendencies towards anti-social and offending behaviour are inhibited or allowed to develop. Weak relationships between parents and children, poor child rearing skills, family discord, low family income, lack of interest in children's activities or schooling and ineffective supervision are all related to 'troublesome' and subsequent offending behaviour. Involvement and interaction of parents with their children and strong family bonding have the potential to protect children against the development of anti-social and offending behaviour.

Every study of the personal and social experiences of known juvenile offenders reveals that almost all of them have endured various kinds of abuse, neglect, deprivation and misfortune (Arthur 2002, 2003, 2004). Juvenile offenders are far more likely than the general population to have been in local authority care, to have suffered family breakdown or loss, to be homeless or insecurely housed and to have experienced child abuse. Neglect by parents, poor maternal and domestic care, family conflict and the absence of a good relationship with either parent have all been shown to increase the risk of behaviour problems and subsequent offending (Utting et al 1993; Yoshikawa 1994). Competent parents show high levels of warmth and support, 
articulate standards for behaviour, monitor their children's behaviour and engage in inductive reasoning and consistent discipline when infractions occur. Parents who rely heavily on harsh punishment or who are erratic in their discipline are twice as likely to have children who offend (Newson \& Newson 1989). Parental monitoring of children is also a key component of positive parenting, both as a predictor of delinquency and as a protective measure as research has confirmed strong links between poor parental supervision and juvenile convictions (Graham \& Bowling 1995).

Poverty is another persistent feature in the lives of young offenders. The aetiological linkages between economic deprivation and juvenile offending are well established in academic criminology and are vividly evidenced in many seminal and defining studies. For example, the Glueck's retrospective comparison of the backgrounds of 500 delinquents and 500 non-delinquents found that $57.4 \%$ of the families involved in their studies had been dealt with by numerous social welfare agencies, largely economic relief organisations (Glueck \& Glueck 1974). Similarly Miller et al analysed the records of 63 children, mostly boys, who were convicted before their $15^{\text {th }}$ birthday and found a "clear excess of delinquent children from families from lower social classes" (Miller et al 1974: 209). Wadsworth, in his national sample, discovered that $4 \%$ of sons of 'upper-middle' families had become delinquent by age 21 compared with $21.9 \%$ of sons from 'lower-manual' families (Wadsworth 1979). These results show that delinquency, as indicated by criminal records, is three times more common among the sons of unskilled manual workers than those of professional and salaried workers. West, in the Cambridge study into delinquent development, also found that family income was a key factor: $33.3 \%$ of boys from low-income families became juvenile offenders compared with $16.7 \%$ of 
boys from higher income families (West 1982). West concluded that future offenders were more likely to have been part of a low income family, lived in run-down housing and shown signs of neglect by their parents. Recidivists with two or more convictions stood out even more starkly, $20 \%$ came from a background of low income compared to just $5.5 \%$ among the rest.

Pursuing the lives of a more recent generation, the Child Health and Education Study of over 13,000 British children born in 1970 has confirmed that antisocial behaviour in pre-school children is consistently associated with social and economic disadvantage (Osborn 1984). In the Newcastle 1,000 Family Study three generations of families were studied over a thirty-year period (Kolvin et al 1990). The survey began by investigating the health of 847 children born in Newcastle-upon-Tyne during May and June 1947. The study was resumed in 1979 and included a comparison between the backgrounds of children who later acquired a criminal record and those who did not. The families were classified as 'non-deprived', 'deprived' and 'multiply deprived' using a variety of measures including parental illness, poor housing, poor mothering and marital instability. The more deprived the family, the more likely it was that their children would offend. By age $33,18 \%$ of the nondeprived children had been convicted of an offence, much less than the $49 \%$ of the deprived and $66 \%$ of the multiply deprived. The findings showed that one in six children living in more affluent districts became offenders compared to one in three in the poorest neighbourhoods.

What emerges from the official crime figures and longitudinal research is that children from low income, working class families are more likely to become juvenile offenders than those from comfortable middle class homes (Bartol \& Bartol 1998; Heimker 1997). Economic hardship has a growing and devastating effect on families 
and influences children through its impact upon parents' behaviour towards children. For example the stress caused by poverty is believed to diminish parents capacity for supportive and consistent parenting. Families living in poverty are often unable to provide the necessary emotional support and stimulation critical to healthy child development. Family incomes and poor housing can also lead to weaker parental supervision and control (Tarling 1993). Thus economic and environmental factors collaborate to make it more difficult to be an effective parent. Economic hardship, even among parents living together and in rural areas, can contribute to parental conflict and poor parenting and consequently to delinquency and other behavioural problems among the children in these families (Conger 1992). Low income and lack of full-time employment have also been shown to increase the likelihood of abuse by parents. Also living in disadvantaged settings can lead to the belief that economic survival through conventional channels is not possible (James 1995; Guerra et al 1995; Henry et al 1993).

The important conclusion from this analysis is that delinquency is found in damaged, and damaging, families. The connection between the difficult family circumstances which plague increasing numbers of children and their subsequent offending behaviour cannot be ignored or denied. The family problems of young people propel them into deviance and subsequently into expanding young offenders' institutions. The corollary of these findings is that children are less likely to offend if their physical, emotional and social needs are met throughout childhood with protection from all forms of neglect, abuse or exploitation. No assertion is being made here that parents are to blame for behavioural problems such as juvenile offending behaviour. Rather, the point being made is that many juvenile delinquents are victims of deprived and depriving families and should be seen as under-socialised individuals 
in need of help and assistance. Given the need to make families function better, the obligation and objective of our society must be to develop and provide the environment, the resources and the opportunities through which families can become competent to deal with their own problems. The family should be assisted in guiding and nurturing the child, through the provision of various resources and support services which equip them to be good parents, reduces their isolation and promotes the welfare of parents and their children. Parents who are bringing up their children in difficult circumstances can be helped to improve their parenting skills and produce better behaved, more trustworthy children who need less expensive supervision and intervention later on. Adults who have practical and social support are in a better position to become effective parents, than those who feel stressed, penalised and alienated. Youth crime prevention policies and interventions therefore need to avoid a narrow focus on the crime and take into account the family, social and contextual factors that are frequently associated with juvenile offending. Accordingly juvenile offending behaviour should be viewed less as a narrow breach of legal codes and more in the wider context of a failure by the family and child to teach and learn, respectively, proper conformity to lawful social order. The evidence from the criminological research emphasises that policies that strengthen the family could be effective as youth crime prevention strategies.

Laws that penalise parents for their children's behaviour ignore the complex patterns and interrelated problems that such families invariably endure. These laws cast parents as 'failures' and confront them with the prospect of financial penalties. The parental responsibility laws exacerbate the impact of risk factors in the lives of youth at greatest risk of offending. The criminological research suggests that in many cases where children are in trouble, the reality of parenthood undoubtedly involves 
vulnerability and poverty, with many parents (especially mothers) living on state benefits and experiencing housing problems. Thus the parents punished for 'failing' are likely to be striving to hold their family together in the face of severe pressures. Punishing parents for a perceived lack of responsibility on their part accelerates family conflict and breakdown. For example these measures aggravate the poverty that lies behind so much anti-social behaviour. Fining parents deprives not only the child whose conduct triggered the court action but also any siblings of at least some measure of the parents financial and personal support. Parental responsibility laws are unlikely to ameliorate any of the damaging family conditions which induce young people into offending behaviour, indeed these laws fail to address the underlying problems and serve to deepen divisions and further alienate vulnerable families. They lead to strains in families where relationships are already tense and fragile and they convert parents and children into adversarial parties in the home.

Recognition of these adverse effects may explain why the courts have been less than enthusiastic in imposing parenting orders, only 3106 parenting orders have been made to date under the Crime and Disorder Act $1998 .{ }^{14}$ There also appears to be a wide variation in the use of parenting orders by the courts. In some areas less than 10 orders were made between spring 1999 and the end of 2001 (Holdaway et al 2001; Youth Justice Board 2001). The criteria for recommending an order appear to lack consistency both within and between YOTs and in some areas they are not supported by adequate resources (Audit Commission 2004). It is difficult to explain entirely the small number of orders, but undoubtedly the reasons outlined above play an important role. Evidence also suggests that the courts see a division of parents into the 'willing' and the 'not bothered', with the latter group being unlikely to respond to anything and the former best treated via voluntary means. 
This apathetic reaction of the courts to parenting orders suggests that the parental responsibility provisions of the Anti-Social Behaviour Act are triggered more by party political needs (Day Sclater 2000; Payne 2003; Muncie 1999b) and represent a continuation of the government's commitment to penal populism and its stated policy to 'nip offending in the bud' (Home Office 1997b). The criminalization of inadequate parenting also resonates with 'new right' underclass theories popular in the 1980s. The American social policy analyst Charles Murray argued that the state welfare system was enabling young mothers to live independently of fathers and thus increased the number of young people growing up without an appropriate male role model. These young people consequently turn to drugs and crime (Murray 1984, 1990). Murray's solution to this was to advocate the removal of state benefits. In Britain Dennis and Erdos (Dennis \& Erdos 1992) expounded similar views. They argued that juvenile crime was the inevitable result of the disintegration of the family unit and the growth of 'fatherless families'. The tragic murder of James Bulger in February 1993 buttressed this climate of blame and created an insistence that parent's make more effort to control and discipline their children or face being held accountable in courts. New Labour, with its focus on individual and parental responsibility and its desire to cement its position on the law and order high ground has continued this trend (Muncie 1999a).

Whilst some of the thinking underlying the parenting order is laudable (the underlying recognition that poor parenting skills may contribute to delinquency), there appears to have been too little thought given to the context of its delivery, the idea of delivering 'supportive' parental programmes in a punitive context is likely to be alienating and counter-productive (Gelsthorpe \& Morris 1999; Goldson \& Jamieson 2002). How much better if parents attended these courses voluntarily, 
before the crisis? If young people are committing offences because their childhood history includes abuse or neglect, poor parental supervision or a failure to equip them with appropriate decision making skills, then it would be more appropriate to assist the family in guiding and nurturing the child through the provision of various resources and support services which reduces their isolation and promotes the welfare of the family. Resources need to be targeted at tackling the established risk factors rather than penalising parents. Such a view is consistent with Britain's obligations under the United Nations Convention on the Rights of the Child and other instruments of international and domestic law, conversely penalising parents for their children's offending behaviour is totally at variance with Britain's duties under international conventions. In the next section I will examine the state's legal duty to provide support and assistance to parents in their efforts to tackle the root causes of youth crime.

\section{The duty to support families: International Law}

The preamble of the United Nations Convention on the Rights of the Child (UNCRC) recalls that the Universal Declaration of Human Rights proclaims "Childhood is entitled to special care and assistance". In accordance with this ideal Article 27 of the Convention on the Rights of the Child provides for the right of every child to "a standard of living adequate for physical, mental, spiritual, moral and social development." Article 18.2 of the UNCRC sets out the obligations of the state to assist parents in raising their children: “...States Parties shall render appropriate assistance to parents and legal guardians in the performance of their child-rearing responsibilities and shall ensure the development of institutions, facilities and services for the care of children." The United Kingdom ratified the UNCRC in 
December 1991, ratification of the United Nations Convention on the Rights of the Child is a commitment binding in international law. Ratifying states are required, as a matter of legal obligation, to protect Convention rights in their law and practice. Thus in England and Wales the state has a conventional obligation to safeguard and promote the general health and welfare of its youngest citizens up to their $18^{\text {th }}$ birthday.

The principles and provisions of the Convention on the Rights of the Child are informed by a number of more detailed Standards and Guidelines, for example the United Nations Standard Minimum Rules for the Administration of Juvenile Justice (the Beijing Rules) 1985 and the United Nations Guidelines for the Prevention of Juvenile Delinquency (The Riyadh Guidelines) 1990. Although these instruments are purely recommendatory and are non-binding in that they have no direct legal impact upon either international or national legislative bodies, they serve to identify current international thinking on human rights for juveniles and they represent the minimum recommended standards on juvenile justice issues. The United Kingdom has committed itself to aspire towards fulfilling all the obligations outlined in these instruments. ${ }^{15}$ Article 1.2 of the Beijing Rules 1985 stresses the idea that the state should ensure a productive life for young people within the community such as to encourage in them a process of personal development and education "during that period in life when she or he is most susceptible to deviant behaviour." ${ }^{16}$ These rules point to the important role that a constructive social policy for juveniles could play in the prevention of youth offending. These broad fundamental perspectives refer to comprehensive social policy in general and aim at promoting juvenile welfare to the greatest possible extent, which will minimise the necessity of intervention by the juvenile justice system, and in turn, will reduce the harm that may be caused by any 
intervention. Such care measures for the young, before the onset of juvenile offending behaviour, are basic policy requisites designed to obviate the need for the application of the Rules.

The 1990 Riyadh Guidelines emphasise that policies should avoid criminalising and penalising a child for behaviour that does not cause serious damage to the development of the child or to others. The Riyadh Guidelines stress that the successful prevention of juvenile delinquency requires efforts on the part of the entire society to ensure the harmonious development of adolescents with respect for, and promotion of, their personality from early childhood. By engaging in lawful, socially useful activities and adopting a humanistic orientation towards society, young people can develop non-criminogenic attitudes. The Riyadh Guidelines recommend that policies and measures should involve the provision of opportunities to meet the varying needs of young people and to serve as a supportive framework for safeguarding the personal development of all young people, particularly those who are demonstrably endangered or at social risk and are in need of special care and protection. The Guidelines support preventive policies which facilitate the successful socialisation and integration of all young people, in particular through the family. Article 33 states that "Communities should provide ... a wide range of communitybased support measures for young persons, including community development centres, recreational facilities and services designed in view of the special problems of children in a situation of social risk."

At the $96^{\text {th }}$ plenary meeting of the General Assembly of the United Nations, ${ }^{17}$ Resolution 40/35 was adopted, which recognised that the prevention of juvenile crime includes measures for the protection of juveniles who are abandoned, neglected, abused and in marginal circumstances and in general those who are at social risk. It 
was also acknowledged that one of the basic aims of the prevention of juvenile crime is the provision of requisite assistance and a range of opportunities to meet the varying needs of the young, especially those who are most likely to commit crime or be exposed to crime, and to serve as a supportive framework to safeguard their proper development. Member States were requested to study the situation of juveniles at social risk and to examine the relevant policies and practices of prevention within the context of socio-economic development and to adopt distinct measures and systems appropriate to the welfare of juveniles at social risk.

The United Nations Convention on the Rights of the Child and the associated Rules and Guidelines are not a part of UK national law therefore it is not possible to bring a challenge in the UK courts where there are grounds for believing that the state is violating Convention rights. This is not to say that the rights in the Convention are totally without protection, the United Nations Committee on the Rights of the Child monitors how states are making progress in securing Convention rights for children within their jurisdiction. The United Nations Committee on the Rights of the Child has repeatedly recommended that the UK establish a system of juvenile justice that fully integrates into its legislation, policies and practice the provisions and principles of the Convention, the Beijing Rules and the Riyadh Guidelines (United Nations Committee on the Rights of the Child, 2002). In particular the Committee on the Rights of the Child recommended that the UK adopt the best interests of the child as a paramount consideration in all legislation and policy affecting children throughout its territory, most notably within the juvenile justice system. Furthermore, the Committee recommended that there be a review of all orders introduced by the Crime and Disorder Act 1998 in order to ensure their compatibility with the principles and provisions of the Convention. 
In addition to this wealth of UN material, the child's right to protection from involvement in anti-social and offending behaviour can be found in instruments of the Council of Europe. In 1987 Recommendation R(87)20, on social reactions to juvenile delinquency, was adopted by the Committee of Ministers of the Council of Europe. The Council of Europe recommended that each of the member states review their legislation and practices in view of putting into practice a global policy of prevention of maladjustment and delinquency. Similar to the various United Nations rules and resolutions, this Recommendation places emphasis on the role of the family and society in the treatment of young people. The exposé of the motives summarises this orientation, "intervention with young people should, as far as is possible, take place in the environment of the young person, with the family being assisted adequately in order that it can contribute to the educational process." ${ }^{18}$ Furthermore in 1996 the Council of Europe adopted a European strategy for children urging member states to fully implement the United Nations Convention as well as relevant European Conventions to ensure children's rights. ${ }^{19}$ Although the recommendations of the Council of Europe are not legally binding they are adopted unanimously and so carry weight and indicate a common approach to policy and minimum standards (Van Beuren 1992).

The philosophy that directs the general principles of the United Nations Convention, Rules and Guidelines, as well as the other international conventions, is essentially based on the protection of the personality of all young people below 18 years of age and on the mobilisation of existing resources within the community. These instruments of international law emphasise the need for prevention policies and interventions to avoid a narrow focus on the crime and to take into account the family, social and contextual factors that are frequently associated with juvenile offending. 
They promote the principle that in order to reduce the risk some children face of becoming offenders, the best strategy is to promote positive life and family experiences for all children, and not to penalise families. They recognise that sometimes parents need extra support to give them the skills and confidence to address their children's behaviour problems and that help should be provided to families where they need it. This view concurs with the overwhelming criminological evidence which explains offending behaviour by reference to the nature of the negative family experiences of children. If juvenile offending behaviour is understood as a phenomenon triggered by negative family factors working upon the innocent individual, then a parentalistic rehabilitation approach might be favoured to correct the problem. Parental responsibility laws contravene these instruments of international law and the criminological research, rather than penalising parents the criminal justice system should seek to help and support families. Instead of penalising families, the state should strive to create the conditions in which families can flourish and all children have the chance to succeed.

In England and Wales many of the tools needed for addressing the risk factors which predispose young people to offending behaviour are in fact already in place. Therefore it is not necessary to legislate in order to ensure that resources of the right kind are available. The obligations of the state to assist families who need help in bringing up their children are laid down in the Children Act 1989. The Children Act 1989 actively promotes strategies and activities that reduce the impact of risk factors, and enhance the influence of protective factors, in the lives of young people and their families. In the next section I will examine the role of the Children Act 1989 in tackling youth offending. 


\section{The duty to support families: the Children Act 1989}

The Children Act 1989 identifies a unique role for the state in helping families to meet their responsibilities, and in providing support to children whose lives include many of the circumstances that have been identified as risk factors for offending. While acknowledging that prime responsibility for children's upbringing lies with parents, the 1989 Act places a duty on local authorities to safeguard and promote the welfare of children within their area who are in need and to provide services specifically aimed at reducing the need for criminal proceedings against children and encouraging children not to commit criminal offences. ${ }^{20}$ The 1989 Act places a duty on local authorities to provide support and services aimed expressly at improving parenting skills, supporting families under stress and discouraging juvenile involvement in crime. ${ }^{21}$ The Children Act 1989 empowers local authorities to develop a holistic preventive approach to youth crime by providing young people and their families with a range of services, including: family support; access to play and leisure opportunities; counselling; improvement of literacy skills and numeracy; engaging young people in suitable education, training or employment; training parents in effective child rearing methods; pre-school intellectual enrichment programmes; reducing school non-attendance; positive opportunities for physical, emotional, social and intellectual development in childhood; alcohol and drug programmes; the provision of day care; promoting healthy and law-abiding living; increasing the protective and resilience factors of siblings and children of those involved in crime; providing access to accredited intervention and offending behaviour programmes; providing families and young people with access to behaviour modification models such as anger management and conflict resolution; and providing respite breaks and family holidays (Department of Health 1991). All of these initiatives provide sound 
foundations for developing youth offending preventive interventions as they pre-date any formal contact with the criminal justice system; improve parenting skills, children's physical and mental health; reduce the risk of child abuse; and reduce many of the risk factors identified in the criminological research. Given that the overriding philosophy of the 1989 Act is that children are best brought up by their families, ${ }^{22}$ these provisions appear to be a general encouragement to local authorities to offer services to families which may be experiencing some of the difficulties examined earlier in this article, so as to try to avoid the worst effects of family conflict and to prevent children engaging in offending behaviour.

The Children Act 1989 also provides local authorities with a statutory mandate to seek the assistance of: the youth justice system, youth offending teams, other local authorities, the police, housing authorities, education authorities, voluntary organisations and other bodies in seeking to fulfil their youth crime prevention duties. ${ }^{23}$ Local authorities are lawfully obliged to make use of and enhance current information sharing protocols, such as ACPC's and child protection conferences, in order to develop systems which will ensure that young people who are at risk of offending are effectively targeted. The legislation also encourages local authorities to consolidate links with pre-offending panels and youth inclusion panels which have a remit to identify young people who are most at risk of offending and in need of services. These important provisions of the Children Act 1989 seek to ensure that the various arms of the public service should cooperate with each other. This is an extremely valuable power which could help to minimise damaging family factors and thus prevent children engaging in offending behaviour. Furthermore in $\operatorname{Re} F ; F v$ Lambeth London Borough Council ${ }^{24}$ Munby J held that a local authority would be acting unlawfully if it failed to ensure effective inter-agency co-operation in the 
manner envisaged by the Children Act. Juvenile offending behaviour should therefore trigger a multi-agency assessment and referral to the most appropriate service through the provisions of the Children Act, rather than penalising families who are struggling to cope.

Local authority duties are also informed and influenced by section 17(1) of the Crime and Disorder Act 1998 which provides that it shall be the duty of each authority to do all that it reasonably can to prevent crime and disorder in its area. This principle is also reaffirmed in section 37 of the Crime and Disorder Act 1998, which places all those carrying out functions in relation to the youth justice system under a statutory duty to have regard to the new principal aim of preventing offending by children and young people. ${ }^{25}$ It is intended that this aim should be achieved through interventions which tackle the particular factors that put the young person at risk of offending (Home Office et al 1998). Paragraph 4 of the 'framework document' for the Crime and Disorder Act 1998 explains the incorporation into statute of this aim, it argues that the youth justice system has for "too long been seen to be separate from wider youth crime prevention work" and that the new statutory aim makes clear the "important link that there should be between the work of the youth justice system and wider work to help prevent children and young people offending" (Home Office 1998). The Crime and Disorder Act places a statutory duty on all local authorities, police forces, police authorities, health authorities and local probation committees to work together in combating problems of crime and disorder in their locality, ${ }^{26}$ and to ensure that all youth justice services are available in their area. ${ }^{27}$

Evidence suggests that encouraging parents to make use of social services and providing families with the types of support examined above may reduce the levels of risk factors associated with youth crime (Olds et al 1997; Welsh et al 2001). 
Programs combining early family support and education, serving low-income families and involving both a child-focussed educational component and a parent-focussed informational and emotional support component represent a promising method of preventing the early onset of chronic juvenile delinquency (Farrington 1996; Yoshikawa 1994). These forms of support, as available under Part III of the Children Act 1989, have the potential to achieve a long-term prevention of anti-social behaviour and delinquency through their effect on multiple early risk factors such as parenting quality and family income.

Parenting support was shown to reduce childhood anti-social behaviour in an experiment conducted in London and Chichester. A randomised controlled trial involving 141 children aged between 3 and 8 years and all displaying high levels of aggression and other behavioural problems, found a large reduction in juvenile antisocial behaviour among those whose parents took part in a parenting support programme. The parenting support programme involved providing information and support to parents to help them become more effective in raising their children; and helping parents to learn family management skills including non-violent discipline (Scott et al 2001; Patterson et al 1992). The authors of the Newcastle 1,000 Families study observed that children from deprived backgrounds who avoided a criminal record had tended to enjoy good parental care and supervision (Kolvin et al 1990). Rutter and Giller made a comparable point in their exhaustive review of the literature on juvenile crime (Rutter \& Giller 1983). They noted that any statistical relationship between economic status and juvenile crime in the Cambridge study disappeared once the influence of poor parental supervision was taken into account. From another longitudinal research project, the Oregon Youth Study which focussed on ten year old boys using criminal records and self-report data, it emerged that the statistical 
connection between socio-economic status and the children's early offending behaviour was entirely mediated by family management practices (Capaldi \& Patterson 1991). In other words, offering parents' support and encouragement can mediate the worst effects of economic pressures, and influence the behaviour of parents and their children.

Pre-school programmes have also been shown to lead to decreases in juvenile offending and anti-social behaviour, school failure and other undesirable outcomes. One of the most successful and best-known delinquency prevention programmes has been the Perry Preschool Programme carried out in Michigan (Smith \& Stern 1997). The project targeted 3 and 4 year old children in disadvantaged communities who were allocated to control and experimental groups. The experimental children attended a daily pre-school programme backed by weekly home visits for up to two years. There was significant evidence that by age 19 the experimental group was less likely to have been arrested and more likely to have graduated from high school (Schweinhart et al 1993). These results become more compelling when viewed in the context of ten other pre-school programmes followed up in the USA (Consortium for Longitudinal Studies, 1983). With quite impressive consistency all studies show that pre-school has long-term beneficial effects on school success and offending behaviour; participating children exhibited fewer antisocial and negative behaviour and showed more positive social behaviour (Webster-Stratton et al 1989). Research also suggests that the influence of pre-school education in disadvantaged children extends into adolescence and beyond, improving their chances of employment success and decreasing the risks of delinquency (Sylva 1994).

The experience of local authorities in coordinating arrangements to protect children from abuse and neglect, their extensive responsibilities in the youth justice 
field, and their role in developing children's service plans makes them most suitable to play a role in youth crime prevention. Local authorities provide a structure which spans youth justice services, social services and child and family welfare services. The Children Act 1989, and related legislation, provide local authorities with the legislative framework needed to deter young people from becoming involved in crime in accordance with Britain's international law obligations and the vast criminological evidence concerning what works in preventing youth offending. Progress towards implementation of the Children Act should progressively ameliorate the conditions which coerce children into engaging in anti-social and offending behaviour by reducing the impact of risk factors. How far the Children Act 1989 will fulfil this preventive aspiration will only be determined by investigating the kind of policies and programmes the local authority develop, the organisation and structure of individual local authorities, and the delivery of services to families.

Unfortunately research findings expose local authorities as taking a less than proactive approach in fulfilling the youth crime prevention role envisaged for them in the Children Act 1989 (Aldgate \& Tunstill 1995; Social Services Inspectorate 2002). The evidence warns that the central philosophy and preventive principles of the Children Act 1989, including youth crime prevention, are being undermined (Colton et al 1995; Social Services Inspectorate 1999). While there exists pockets of effective and innovative practice in local areas, the resourcing of preventive efforts simply does not match the scale of the problem. At a macro level policy trends have served to promote rather than reduce criminality. Youth work has found itself vulnerable to cuts in local authority spending. Increases in family breakdown and child poverty have coincided with reductions in the ability of local authorities to undertake preventive social work. Thus overburdened local authorities are reluctant to take on the youth 
crime prevention responsibilities of the Children Act. This reality makes it practically impossible to carry out the necessary interventions to support and facilitate the family strengthening philosophy of this article.

The central philosophy and preventive principles of the Children Act 1989 and the related international law, including youth crime prevention, are being undermined because the family support aspirations and provisions of the 1989 Act are being implemented partially and not prioritised (Farmer \& Owen 1995). Therefore the problem is not a matter of law, but its implementation. The parental responsibility laws which penalise parents for their children's anti-social and offending behaviour are being used to fill this vacuum, despite the fact that these laws fail to acknowledge the need for, let alone provide, a means to tackle the social and familial roots of youth crime and disorder. The Home Office Minister Hazel Blears described the provisions of the Anti-Social Behaviour Act 2003 as essential for persuading parents to "face up to their responsibilities for the good of their children and the benefit of the wider community" (Department for Education and Skills 2004). Education Minister Ivan Lewis asserted that where parents are simply unwilling to fulfil their responsibilities, "it must be right that society demands legal sanctions." These comments disregard the evidence examined in this article which shows that the state as well as the offender has some responsibility for juvenile crime; the state is failing to provide young offenders and their families with the help they need; and therefore the state is failing to fulfil their duties under domestic and international law. Given this evidence I therefore posit that the state can justifiably punish young offenders for their crimes only to the extent it has fulfilled its obligations to those young people as members of society. Just as the state has not been slow to enlist and enforce the co-operation of 
parents in the fight against youth crime, so families should now feel entirely justified in demanding the full co-operation of the state.

If juvenile offending behaviour is to be seriously addressed, the value of services for young people and their families should be recognised as an investment for the future of the families involved and the community as a whole. Policy responses to juvenile offending should no longer be predicated upon a conceptualisation of a demonised, threatening and lawless youth (Goldson 1999), but instead should reflect the research which proves that most young offenders have suffered a vulnerable, abusive and disadvantaged childhood. If efforts were focussed on providing help to troubled children, there should be less need for punishing children and families in trouble.

\section{Conclusion}

An effective youth crime reduction and prevention philosophy is one that addresses the life experiences of children and in which prevention is promoted through the collaborative and integrated activities of a range of services. Increasingly punitive measures used to deal with young offenders and their families camouflage the state's unwillingness to maintain a social infrastructure that provides parents with the support, resources and services they need to care for their children. The parental responsibility laws oversimplify the complex linkage between parenting and delinquency in a reductionist effort to blame parents for their children's wrongs. If the government is serious about tackling juvenile offending behaviour then rather than penalising parents, resources must be allocated to intervene positively in young people's lives to prevent them engaging in offending behaviour. The Children Act 1989 offers a means of providing a proactive programme of support for young 
offenders and their families. The Children Act represents the linchpin for the development of an effective and supportive multi-agency youth crime prevention strategy. Where the Children Act fails is in the application, operation and interpretation of legislative provisions. A progressive approach to youth crime prevention is ultimately bound up with the pursual and adequate resourcing of the Children Act. Such an approach should help to keep children and parents out of the criminal justice system, an already overcrowded system where vulnerable and needy families do not belong.

\section{ACKNOWLEDGEMENTS}

I would like to thank Prof. John Hatchard and Prof. Gary Slapper for their comments on earlier drafts of this paper. However, opinions expressed herein, together with any errors remain the responsibility of the author.

\section{NOTES}

\footnotetext{
${ }^{1}$ Delinquents and young offenders refer to young people aged between 10 and 16 years and convicted of an offence.

${ }^{2}$ The Criminal Justice and Public Order Act 1994 extended this power to include parents having to ensure their child's compliance with the requirements of a community sentence.

${ }^{3}$ Section 150(1) Powers of Criminal Courts (Sentencing) Act 2000

${ }^{4}$ Section 150(1)(a) Powers of Criminal Courts (Sentencing) Act 2000

${ }^{5}$ Hansard, Vol. 149, col. 767

${ }^{6}$ Any young person aged between 10 and 16 years and convicted of an offence.

${ }^{7}$ Section 8(7A) Crime and Disorder Act 1998 as amended by section 18 Anti-Social Behaviour Act 2003

${ }^{8}$ Section 8(1) Crime and Disorder Act 1998

${ }^{9}$ Under section 11 Crime and Disorder Act 1998

${ }^{10}$ Under section 1 and section 2 Crime and Disorder Act 1998

11 Section 324 and Schedule 34(2)(3) Criminal Justice Act 2003. Part III of the Powers of Criminal Courts (Sentencing) Act 2000 provides that the referral order is to become the standard sentence imposed by the Youth Courts, or other Magistrate Court, for all first time offenders under the age of eighteen unless their offending is so serious that it warrants custody.

${ }^{12}$ Section 20 Anti-Social Behaviour Act 2003

${ }^{13}$ Hansard 18 July 2003 Col 1092

${ }^{14}$ per Parliamentary Under-Secretary of State for the Home Department, Bob Ainsworth, Hansard, $8^{\text {th }}$ May 2003, Col 102

${ }^{15}$ The 'Beijing Rules' have been approved by each of the members of the United Nations. In 1985 the Beijing Rules were adopted by the Committee of Ministers of the Council of Europe.

${ }^{16}$ The United Nations Rules on the Administration of Juvenile Justice ('Beijing Rules') 1985.

${ }^{17}$ New York, $29^{\text {th }}$ November 1985
} 


\footnotetext{
${ }^{18}$ Adopted by the Committee of Ministers on 17 September 1987 at the 410th meeting of the Ministers' Deputies. This Recommendation was based on the work of a committee of experts from 17 European Countries which met between 1983-1987.

${ }^{19}$ Parliamentary Assembly of Europe, Recommendation 1286, 1996

${ }^{20}$ Section 17 \& Schedule 2 para 7 Children Act 1989

${ }^{21}$ Schedule 2, paragraph 7(a)(ii) provides that every local authority shall take reasonable steps designed to reduce the need to bring criminal proceeding against such children and paragraph 7(b) requires local authorities to encourage children within their area not to commit criminal offences.

${ }^{22}$ Section 17(1) Children Act 1989

${ }^{23}$ Section 17(5) and Section 27 Children Act 1989

${ }^{24}$ [2002] 1 FLR 217, para. 30

${ }^{25}$ Crime and Disorder Act 1998, Section 37(1): "It shall be the principal aim of the youth justice system to prevent offending by children and young people". Section 37(2): "In addition to any other duty to which they are subject, it shall be the duty of all persons and bodies carrying out functions in relation to the youth justice system to have regard to that aim".

${ }^{26}$ Section 5 Crime and Disorder Act 1998

${ }^{27}$ Section 38 Crime and Disorder Act 1998
}

\section{REFERENCES}

Aldgate, J., Tunstill, J. (1995) Making Sense of Section 17. Implementing Services for Children in Need within the 1989 Children Act London: HMSO.

Arthur, R. (2002) "Tackling Youth Crime: Supporting Families in Crisis" Child and Family Law Quarterly 4, 401-426.

Arthur, R. (2003) "Preventing Youth Crime-The Role of the Child Care Act 1991" Irish Law Times 21, 9, 134-137.

Arthur, R. (2004) "Young Offenders: Children in Need of Protection" Law and Policy $26,3 \& 4,309-327$.

Audit Commission (2004) Youth Justice 2004: A review of the reformed youth justice system London: Audit Commission.

Bartol, C.R., Bartol, A.M. (1998) Delinquency and Justice: A Psychosocial Approach $2^{\text {nd }}$ ed. New Jersey: Prentice Hall.

Capaldi, D.M., Patterson, G.R. (1991) "Relation of parental transition to boys' adjustment problems: (i) a linear hypothesis. (ii) Mothers at risk for transitions and unskilled parenting” Developmental Psychology 27, 3, 489-504.

Colton, M., Drury, C., Williams, M. (1995) Staying Together. Supporting Families under the Children Act Arena, Aldershot.

Conger, R.D. (1992) "A family process model of economic hardship and adjustment of early adolescent boys." Child Development 63, 526-541.

Consortium for Longitudinal Studies (1983) As the twig is bent ... Lasting effects of pre-school programmes Hillsdale, NS, Erlbaum. 
Day Sclater, S. (2000) "Re-moralising the family? Family policy, family law and youth justice" Child and Family Law Quarterly 12(2), 135-158.

Dennis, N., Erdos, G. (1992) Families without fatherhood London: London Institute of Economic Affairs.

Department for Education and Skills (2004) Anti-Social Behaviour Powers to Offer Parents Support and Sanction Press Notice 2004/0031.

Department of Health (1991) The Children Act 1989 Guidance and Regulations Volume 2 Family Support, Day Care and Educational Provision for Young Children London: HMSO.

Farmer, E., Owen, M. (1995) Child Protection Practice: Private Risks and Public Remedies: A Study of Decision-Making, Intervention and Outcome in Child Protection Work London, HMSO.

Farrington, D.P. (1996) Understanding and Preventing Youth Crime York: Joseph Rowntree Foundation.

Gelsthorpe, L., Morris, A. (1999) "Much ado about nothing - a critical comment on key provisions relating to children in the Crime and Disorder Act 1998" Child and Family Law Quarterly 11: 209-222.

Glueck, S., Glueck, E. (1974) Of Delinquency and Crime: A panorama of years of search and research Springfield, Illinois, Charles C. Thomas.

Goldson, B. (1999) "Punishing times for children in trouble: Recent developments and the Crime and Disorder Act 1998" Representing Children 11(4), 274-288, p.274.

Goldson, B., Jamieson, J. (2002) "Youth Crime, the 'Parenting Deficit' and State Intervention: A Contextual Critique" Youth Justice 2, 82-99.

Graham, J., Bowling B. (1995) Young People and Crime London: Home Office Research Study 145.

Guerra, N.G., Huesmann, L.R., Tolan, P.H., Van Acker, R., Eron, L.D. (1995) "Stressful events and individual beliefs as correlates of economic disadvantage and aggression among urban children" Journal of consulting and clinical psychology 63, 518-528.

Heimker, K. (1997) "Socio-economic status, subcultural definitions and violent delinquency" Social Forces 75, 3, pp.799-833.

Henry, B., Moffitt, T.E., Robins, L., Earls, F., Silva, P.A. (1993) "Early familial predictors of child and adolescent antisocial behaviour: Who are the mothers of delinquents?" Criminal Behaviour and Mental Health 3: 97-118. 
Holdaway, S., Davidson, N., Dignan, J., Hammersley, R., Hine, J., Marsh, P. (2001) New strategies to address youth offending. The national evaluation of the pilot youth offending teams London: RDS Occasional Paper No. 69.

Home Office (1990) Crime, Justice and Protecting the Public Cmnd. 965 London: HMSO.

Home Office (1997a) Tackling Youth Crime Home Office Consultation Paper, London: HMSO.

Home Office (1997b) No More Excuses: A New Approach to Tackling Youth Crime in England and Wales Cm 3809 London: HMSO.

Home Office (1998) Youth Justice: Preventing Offending London: HMSO.

Home Office (2003) Respect and Responsibility - Taking a Stand Against Anti-Social Behaviour Cm 5778, London: Home Office.

Home Office, Department of Health, Welsh Office, Department for Education and Employment (1998) Inter-Departmental Circular on Establishing Youth Offending Teams London: Home Office.

James, O. (1995) Juvenile Violence in a Winner-Loser Culture Free Association Books: London.

Kolvin, I., Miller, F.J.W., Scott, D.M., Gatzanis, S.R.M., Fleeting, M. (1990) Continuities of Deprivation? The Newcastle 1000 Family Study Aldershot, Avebury.

Miller, F., Court, S., Knox, E., Brandon, S (1974) The School Years in Newcastleupon-Tyne London: Oxford University Press.

Muncie, J. (1999a) Youth and Crime - A Critical Introduction London: Sage.

Muncie, J. (1999b) "Institutionalized intolerance: youth justice and the 1998 Crime and Disorder Act" Critical Social Policy 19:2, 147-175.

Murray, C. (1984) Losing Ground New York, Basic Books.

Murray, C. (1990) The Emerging Underclass London: London Institute of Economic Affairs.

Newson, J., Newson, E. (1989) The extent of parental physical punishment in the UK London: Approach.

Olds, D.L., Eckenrode, J., Henderson, C.R., Kitzman, H., Powers, J., Cole, R., Sidora, K., Morris, P., Pettitt, L.M., Luckey, D. (1997) "Long-term effects of home visitation on maternal life course and child abuse and neglect. Fifteen year follow-up of a randomised trial" Journal of the American Medical Association 18, 637-643. 
Osborn, A.F. (1984) The social life of Britain's five-year olds: a report of the child health and education study London, Routledge \& Kegan Paul.

Patterson, G.R., Reid, J.B., Dishion, T.J. (1992) Antisocial Boys Eugene, Oregon.

Payne, L. (2003) “Anti-Social Behaviour” Children \& Society 17, 321-324.

Rutter, M., Giller, H. (1983) Juvenile Delinquency: trends and perspectives London, Penguin.

Schweinhart, L.J., Barnes, H.V., Weikart, D.P. (1993) Significant benefits: the High/Scope Perry pre-school study through age 27 Ypsilanti,: Mich; High/Scope Press.

Scott, S., Spender, Q., Doolan, M., Aspland, H. (2001) "Multi-centre controlled trial of parenting groups for childhood antisocial behaviour in clinical practice" British Medical Journal 323, 194-196.

Smith, C.A., Stern, S.B. (1997) "Delinquency and antisocial behaviour: a review of family processes and intervention research" Social Science Review September, 382420.

Social Services Inspectorate (1999) Getting Family Support Right: Inspection of the Delivery of family Support Services London, Stationery Office.

Social Services Inspectorate (2002) Safeguarding Children. A Joint Chief Inspectors' Report on Arrangements to Safeguard Children London: Department of Health.

Straw, J. (1998) "New Approaches to Crime and Punishment" Prison Service Journal 116: $2-6$.

Sylva, K. (1994) "The impact of early learning on children's later development" in Ball, C. (ed.) Start Right, The Importance of Early Learning London, Royal Society for the Arts, Manufacturing and Commerce.

Tarling, R. (1993) Analysing Offending Data, Models and Interpretations Home Office Research and Planning Unit, London: HMSO.

United Nations Committee on the Rights of the Child (2002) Consideration of Reports Submitted by State Parties Under Article 44 of the Convention. Concluding observations: United Kingdom of Great Britain and Northern Ireland CRC/C/15/Add.188 Geneva: Committee on the Rights of the Child.

Utting D., Bright J., Henricson C. (1993) Crime and the family: improving childrearing and preventing delinquency. London: Family Policy Studies Centre.

Utting, D. (1996) Reducing criminality among young people: a sample of relevant programmes in the United Kingdom. A Research and Statistics Directorate Report. London: Home Office. 
Van Beuren, G. (1992) "Child Oriented Justice-An International Challenge to Europe" International Journal of Law, Policy and the Family 6, 3, 381-399.

Wadsworth, M.E.J. (1979) Roots of Delinquency London: Martin Robertson.

Webster-Stratton, C., Hollinsworth, T., Kolpacoff, M. (1989) "The long-term effectiveness and clinical significance of three cost-effective training programs for families with conduct-problem children" Journal of Consulting and Clinical Psychology 57, 4, 550-553.

Welsh, B.C., Farrington, D.P., Sherman, L.W. (2001) Costs and Benefits of Preventing Crime Boulder, Colorado: Westview Press.

West, D.J (1982). Delinquency: Its Roots, Careers and Prospects London: Heinemann.

Youth Justice Board (2001) The Preliminary Report on the Operation of the New youth Justice System London: YJB.

Yoshikawa, H. (1994) "Prevention as cumulative protection: Effects of early family support and education on chronic delinquency and its risks" Psychological Bulletin $115,28-54$. 